\title{
1. Introduction: governance, the state and public policy in a global age
}

\section{Patricia Kennett}

\section{INTRODUCTION}

Public policy is located within an increasingly complex, multiple and overlapping network of interactions which are embedded in a transnational and subnational polity and economy. This collection is concerned with exploring the nature of the policy arena in the context of globalization and the reconstitution of the state. Many of the key cornerstones of public policy analysis have become problematic as processes of globalization have disrupted the traditional analytical and conceptual frameworks through which policymaking and implementation have been understood. The reorientation of the role of the state, the increasing variety of terrains and actors involved in the making of public policy, and the transition from government to governance are all aspects of a changing environment, the implications of which need to be captured within contemporary analysis.

It is against this backcloth that the contributors to this collection seek to broaden, extend and integrate theoretical, conceptual and substantive policy debates. This first chapter will focus particularly on the broad themes of governance and globalization and the relationship between them. It will consider various interpretations of governance, the implications for the state, and the institutions, actors and processes involved in the making and implementation of public policy. The chapter will conclude with an introduction to the structure, organization and content of the remaining contributions to the collection.

\section{THE GLOBAL CONTEXT}

The contested and linked concepts of globalization and governance have become firmly established in academic and political debates. There are a myriad of interpretations, as well as a spectrum of opinion on the extent, nature and implications of the phenomena. Globalization can be perceived 
as an economic, ideological, political and institutional project facilitated and enabled through a technological revolution, an ideological and policy shift, a strengthening of the role of international financial institutions and a changing geopolitical landscape (Giddens, 1999; Held and McGrew, 2000, 2002).

Debates about and definitions of governance have emerged at different spatial scales, and from within different types of institutions and academic fields. The term 'governance' has been utilized in a range of countries across Western Europe, the USA, Canada, Australia and New Zealand, and has subsequently become a dominant theme in international organizations, particularly the World Bank and the United Nations. In Western literature it is mainly concerned with the idea of a change from the realist perception of old government and the Westphalian system, whereby the world is organized into territorially exclusive, sovereign nation states, each with an internal monopoly of legitimate violence, to new governance. The former is characterized as having a governing administration which is regarded as the key dominant actor in the policy arena. Internally there exists a clear hierarchy of authority and governing is seen as a top-down, hierarchical process, with the nation state taking centre stage. However, with the change from government to governance the governing administration is now only one player amongst many others in the policy arena. The policy arena has become visibly more crowded, there are more actors involved, the boundaries between the public and the private sphere are less precise and the government's command over the policy process is said to have been transformed (Kjaer, 2004; Newman, 2005).

For Richards and Smith (2002):

'Governance' is a descriptive label that is used to highlight the changing nature of the policy process in recent decades. In particular, it sensitises us to the ever increasing variety of terrains and actors involved in the making of public policy. Thus, it demands that we consider all the actors and locations beyond the 'core executive' involved in the policy-making process. (p. 2)

According to Newman (2005) 'the image of a hierarchical relationship between state and citizenry . . . is displaced by the idea of multiple parallel spaces in which power is encountered and negotiated' (p. 4). Whilst Stoker (1998) supports a general view that governance is about styles of governing in which the boundaries between and within the public and private sectors have become blurred, he asserts that the 'essence of governance is its focus on governing mechanisms which do not rest on recourse to the authority and sanctions of government' (p. 17). Rhodes (1996; also see 2000), in an attempt to establish the meaning of 'governance' and its usefulness for understanding the evolution of the British state, identified six separate uses of the term 
as a minimal state, corporate governance, the new public management, 'good governance', socio-cybernetic system, and as self-organizing networks.

In identifying an interpretation of governance as a socio-cybernetic system Rhodes (1996) is drawing primarily on the work of Kooiman (2003) for whom a major area of concern is the relationship between government and society. Kooiman (2003) is concerned with making governing relationships productive through notions of socio-political governance, or interactive governance between different societal and political actors. Concepts of diversity, dynamics and complexity are central features of governance itself. The socio-political system is increasingly differentiated, characterized by multiple centres and is one in which 'Actors are continuously shaped by (and in) the interactions, in which they relate to each other' (Kooiman, 2003 , p. 2). It is the role of government to enable interactions, encourage many and varied arrangements for coping with policy, and ensure equitable distribution of services between actors through self- and co-regulation and public-private partnerships, or what Kooiman calls 'types of societal interactions' and 'modes and orders of governance'. However, for Kooiman no single governing agency is able to realize legitimate and effective governing:

No single actor, public or private, has all knowledge and information required to solve complex, dynamic and diversified problems; no actor has sufficient overview to make the application of needed instruments effective; no single actor has sufficient action potential to dominate unilaterally in a particular governing model. (Kooiman, 1993, p. 4)

Within the context of what Rhodes (1997) calls a 'differentiated policy' he identifies a fragmented and dispersed pattern of service delivery and regulation. For Rhodes, recent global political and economic shifts have limited the capacity of nation states to govern. These changes have taken place in an ideological climate hostile to 'big government', leading to a series of reforms producing both a reduction in the size of the machinery of government and its fragmentation. Drawing on the experiences of Western democracies, Pierre (2000) refers to these developments as a challenge to the state 'from within' as institutional arrangements of the postwar period were perceived as the source of poor economic performance, and barriers and impediments to effective competition within states and in the increasingly important international markets. As Pierre (2000) explains:

For Reagan, Mrs Thatcher, Mulroney and their ideological followers in several other countries the recipe to alleviate these problems was a firm monetarist economic policy coupled with deregulation, privatization, drastic reductions in the civil service, the introduction of 'managerialism' in the public sector, and a profound institutional restructuring of the state creating semi-autonomous agencies 
to replace governmental centres of command and control functions, i.e. the creation of a minimalist state. (pp. 1-2)

Rhodes (1997) contends that central government's authority, autonomy and power have been reduced by being dispersed - upward to the supranational level, for example Europe, the International Monetary Fund and the G7 (G8 including Russia); outwards through privatization and market testing; and downwards through the creation of agencies and quangos. A 'differentiated policy' requires a new form of coordination which, according to Rhodes (1997), emerges through networks. These policy networks are increasingly influential as policymaking in central government occurs not through formal institutions but through contacts and informal networks. So a crucial element of governance is the shift from markets and hierarchies towards networks and partnerships as modes of coordination (Marsh and Smith, 2000), or what Stoker (1998) refers to as 'the ultimate partnership activity' of autonomous self-governing networks of actors (also see Atkinson and Coleman, 1992) involved not just in influencing policy decisions but also in the business of government itself.

\section{GLOBALIZATION AND NEW FORMS OF GOVERNANCE}

Although not the only factor shaping the nature of governance, globalization is clearly a crucial context in which the policy process should be understood (Hudson and Lowe, 2004). For Cerny (1999) it is economic structural change that is at the heart of globalization in that it challenges deeply embedded socio-cultural and political structures in critical ways . . . provoking dynamic responses of promotion, accommodation, and resistance' (p. 199), both within and beyond the state. It is the nature of competition in this changing environment that has had the major impact on governance structures as the marketized, competitive state 'searches for effectiveness in an increasingly economically penetrated world' (Cerny, 1999, p. 199).

The political and ideological context through which globalization was able to flourish was one in which there was a major shift in the orientation of economic and policymaking and a fundamental 'breakdown of the economic policy consensus that had brought in its train more than two decades of almost uninterrupted economic growth and prosperity in the industrial North' (Weiss, 1991, p. 144). The post-Second World War Bretton Woods system of closed capital accounts and fixed exchange rates, and the modest and gradual approach of the General Agreement on Tariffs and Trade 
(GATT) to trade liberalization, came to an end during the 1970s. Over the next decade a policy environment was established that facilitated economic integration and capital mobility through the deregulation of financial markets and the removal of most of the restrictions on capital flows. In 1995, the creation of the World Trade Organization (WTO), after eight years of complex and difficult negations, heralded a transformation in the multilateral trading regime. The WTO, made up of 184 member governments, has a much wider remit than its predecessor, moving beyond tariffs and trade in goods to include agriculture, standard-setting, intellectual property and services. In addition the 'single undertaking' binds member governments to all WTO agreements, and its dispute system is legally binding (Sinclair, 2003). Increasing competition in global markets, pressure from international institutions, domestic policy decisions to reduce national barriers to international economic transactions, combined with the impact of new technologies, 'created the enabling conditions for the onset of globalization' (Biersteker, 1998, p. 24).

More recently, in the context of an established, yet still evolving globalization and governance architecture, new forms of governance have emerged involving what Rosenau (1990) refers to as the increasing relevance of private, 'sovereignty-free actors', multinational corporations, transnational societies and international governmental and non-governmental organizations. The dominance of market-driven approaches to stimulate growth and competitiveness has, according to Wilkinson (2005), 'recast transnational corporations into mobilisers of capital, generators of technology, and legitimate international actors with a part to play in an emerging system of global governance' (p. 37).

The growing visibility of non-governmental organizations (NGOs) and social movements in the global arena has generated powerful debate, at a time when traditional, nationally based channels of participation (for example membership of a trade union or political party, voting turnout) have been in decline. Concern regarding the social and environmental impacts of globalization, corporate 'irresponsibility' and unsustainable growth, as well as the nature of emerging governance structures, became particularly apparent during the 1990s. The 'democratic deficit' and lack of transparency in the powerful international institutions has been, and continues to be, a major issue, as was the growing awareness of the negative impact of the neoliberal strategies these institutions were advocating and implementing during the 1980s, particularly in the countries of the South. The Human Development Report (UNDP, 2000) points to the role of civil society actors in maintaining pressure on national governments, international agencies and corporations to protect human rights and environmental standards. In the year 2000 there were more than 37000 NGOs - nearly 
one-fifth of them formed in the 1990s. Around the world there are more than 20000 transnational NGO networks, and more than $\$ 7$ billion in aid to developing countries now flows through international NGO activity (UNDP, 2002).

Rhodes (1996) argues that 'Government reform is a world-wide trend and "good governance" is the latest flavour of the month at the World Bank, shaping its lending policy towards Third World countries' (p. 656). This is in contrast to the 1980s when the Washington Consensus, incorporating the familiar neoliberal themes of deregulation, privatization and the liberalization of trade, was considered the most appropriate model of economic and political management. This was a reflection of the new economic orthodoxy emerging in the North which was promoted by the most powerful state players and subsequently transmitted to developing societies through the influential international financial institutions. The response of the World Bank and the International Monetary Fund (discussed in more detail in Chapter 6) to sustained criticism not only of the negative impact of their structural adjustment programmes, but also in relation to issues of accountability and transparency, has been to turn instead 'toward embedding, legitimating and securing reform' (Porter and Craig, 2004, p. 390) through 'inclusivity', extending their association with civil society in the policymaking process and promoting a form of 'good governance' that 'marries the new public management to the advocacy of liberal democracy' (Rhodes, 1996, p. 656). Eyoh and Sandbrook (2001) characterize this approach as one of 'pragmatic neo-liberalism' which has been particularly apparent since 1999 and the introduction of the Comprehensive Development Framework (CDF). According to the World Bank the CDF promotes a more holistic, participatory and country-owned approach to poverty reduction through Poverty Reduction Strategy Papers which require national governments to reassess their relationship and engage with civil society in the policy arena.

The proliferation of NGOs and their increasing visibility in world politics and policy has also been promoted and reinforced by the rhetoric of decentralization, local participation, self-help and partnership which has, in turn, contributed to the development of new collaborative forms of governance. These developments have received 'ringing endorsements . . from widely distant points on the ideological spectrum' (DeMars, 2005, p. 34). They are perceived from the Right as an appropriate alternative to national governments, from the moderate left as a democratizing force promoting accountability and social rights, and from the more radical Left as a potential force for 'a counter-hegemonic project that would eventually yield revolutionary change' (DeMars, 2005, p. 34). The novel forms of participatory governance, the emergence of a 'global civil society', and the 
transnational political networks put in place by actors in civil society challenge the state from below (Lipschutz, 1992). For Lipschutz 'the growth of global civil society represents an ongoing project of civil society to reconstruct, reimagine, or re-map world politics' (ibid., p. 291).

Whilst it is evident that new forms of politics, representation and layers of governance (Swyngedouw, 2005; Richards and Smith, 2002) are emerging, both internationally and locally, one cannot yet confirm the arrival of multilayered public governance (Scholte, 2000; Held et al., 1999) or a strong global governance. As Jessop (2004) argues, there is still substantial scope for the state 'to mediate between the increasing numbers of significant scales of action' (p. 18). Participatory processes appear to have remained relatively weak. Within some developing countries the process has been more one of consultation than participation and in some cases has been 'limited to giving feedback on complete draft documents or voicing opinions at large consultation workshops' (McGee et al., 2002). It has also been perceived as an externally imposed condition by some governments which are required by the donors to implement broad-based participatory processes to produce Poverty Reduction Strategy Papers.

So whilst the emphasis is on country ownership, policy autonomy and the mainstreaming of poverty reduction policies there remains a tension between national autonomy and policy conditionality imposed by IFIs. The World Bank is the largest provider of long-term development finance for poor countries. Its concessional development arm, the International Development Association, provided $\$ 8.7$ billion in aid to developing countries (Oxfam International, 2006). The International Monetary Fund (IMF), although initially assigned the role as a worldwide central bank, has become almost a 'permanent fixture' (Oxfam, 2006) in developing countries, as the activities of the World Bank and the IMF have converged. According to Oxfam (ibid.) the IMF has a gatekeeper role, 'in that nearly all official development donors tie their aid and debt relief to the presence of an IMF lending programme'. Thus the economic conditions the IMF attaches to its lending are highly influential on national policies and thus on the content of the country-prepared PRSPs as governments seek endorsement. 'If a poor country does not fulfil IMF conditions it risks losing both IMF finance and all other sources of aid and debt relief tied to the IMF programme' (ibid., p. 9).

Commenting on the effectiveness and extent of 'inclusive' participatory processes, Clarke et al. (2005) conclude that simply because there has been a substantial increase in the number of non-state actors, this does not automatically translate directly into more systematic participation within international governmental organizations or mean that states and international organizations uniformly respond to NGO 'knocks' by opening the 
intergovernmental 'doors' (Clarke et al., p. 294). More important is an assessment of the nature and quality of procedures governing civil participation. In their assessment of three United Nations World Conferences held in the 1990s Clark et al. (2005) did find evidence of the development of 'shared procedural repertoires' between NGOs, and 'deepening common frameworks' between NGOs and states. However, their overall conclusion was that: 'States continue to dominate the procedures and the substance of interaction on key sovereignty-related issues' (p. 295), and ultimately it is 'State sovereignty [that] sets the limits of global civil society' (p. 314).

\section{GOVERNANCE AND THE STATE}

A central concern of the globalization and governance debate has been the implications of global integration for the state. As Pierre (2000) points out:

The overarching question is what significance or meaning remains of the liberaldemocratic notion of the state as the undisputed centre of political power and its self-evident monopoly of articulating and pursuing the collective interest in an era of 'economic' globalisation, a hollowing out of the state, decreasing legitimacy for collective solutions, and a marketisation of the state itself. Is it the decline of the state we are witnessing, or is it the transformation of the state to the new type of challenges it is facing at the turn of the millennium? (p. 2)

As Rose and Miller (1992) argue, simply 'relocating aspects of government in the private or voluntary sectors does not necessarily render them less governable (p. 200). It is not about a reduction in government, rather the dispersal of government power across new sites of action, augmented through new strategies and technologies. Whilst global processes can clearly be associated with the changing nature of constraints faced by the state, and patterns of interaction between and within states, this is not to say that national governments no longer have any importance but rather that the things they are able to do are different and are done through a new array of institutions and relationships. Jessop (2004) characterizes the contemporary policy arena as one of 'unstructured complexity' (p. 17), in which national governments, international organizations, firms, International Governmental Organizations (IGOs) and NGOs, and civil society might provide governance services in many different combinations (McGinnis, 2000), as indicated in the subsequent chapters in this book.

States remain key players in regulating and directing economic and political globalization - they are not passive players but primary architects. We might therefore speak of state adaptivity rather than state retreat (Weiss, 1998). More recently, Weiss (2005) has referred to a process of 'state 
augmentation' in which globalization is reinforcing the role of national institutions. She argues that:

there is strong evidence that in the contemporary period the growth of the state has gone hand-in-hand with the rise of global corporations and multilateral institutions, and that these contemporary global networks remain intimately entwined with the domestic structures of nation states. As national networks have grown, so too have transnational ones. This is a story of structural and political entwinement, of mutual reinforcement, rather than of power displacement. (p. 346)

Swyngedouw (2005) highlights a threefold organization of governing contributing to a 'rearrangement of the relationship between state, civil society and the market' (p. 1998). This involves the externalization of some state functions through privatization, deregulation and decentralization; the downscaling of governance to incorporate 'local' practices and arrangements (p. 1998); and the upscaling of regulatory functions and other roles to supranational levels of governance, such as the EU, IMF and WTO. This governance structure is accompanied by polycentric ensembles and horizontal networks of association between private, civil society and state actors (Swyngedouw, 2005) operating within what Hajer (2003) has referred to as an 'institutional void'. According to Swyngedouw (2005), 'the rescaling of policy transforms existing power geometries, resulting in a new constellation of governance articulated via a proliferating maze of opaque networks, fuzzy institutional arrangements, ill-defined responsibilities and ambiguous political objectives and priorities (p. 1999). However, central to these arrangements is the state which plays a pivotal role in establishing the contours and content of this new form of networked governance.

Jessop (2004) reinforces the argument that the state has never existed 'in majestic isolation overseeing the rest of society but is embedded in a wider political system, other institutional orders, and the life world' (p. 12). The state itself, as well as its relationship with other institutional forms, is 'historically variable and socially constructed' (p. 12). Jessop (2004) refers to a series of counter-trends evident in the current reorganization of the national state. The dispersal of state power and activities to actors, networks and institutions at different spatial scales represents the denationalization of statehood. However, this very dispersion has created sites for the emergence of new state powers, albeit at different territorial scales - and this represents the reterritorialization of the national as the state seeks to play a central role in this 'unstructured complexity as different scales of economic and political organisation proliferate and different scale strategies are pursued' (p. 17). Thus, according to Jessop, the shift from government to governance (or de- and restatization) has not weakened the role of 
the state; on the contrary it is precisely because of these trends towards the blurring of the boundaries between the public and private, and changing relationships between organizations, that the new responsibilities at different spatial scales have emerged.

The governmentality approach also reinforces the notion that the neoliberal state 'not only retains its traditional functions, but also takes on new tasks and functions' (Lemke, 2001, p. 201). Central to the notion of governmentality are the concepts of political rationality and technologies of government (Foucault, 1996). Political rationality, according to Lemke (2001), refers to a discursive field in which excercising power and forms of action are 'rationalised'. This rationalization occurs through the emergence of concepts, arguments and justification, and the creation of objects. Lemke argues that political rationality 'constitutes the intellectual processing of the reality which political technologies can then tackle'. Thus, a form a reality is constructed for which particular political technologies are then deemed appropriate, and instigated through various institutions, agencies and legal forms (Barry et al., 1996; Burchell et al., 1991). For Foucault (1982), government is also about the 'conduct of conduct', involving the governing of self as well as governing others and, according to Lemke (2001), how the modern state and the modern autonomous individual co-determine each other's emergence. The state is itself a tactic of government, 'since it is the tactics of government which make possible the continual definition and redefinition of what is within the competence of the state and what is not, the public versus the private, and so on' (Lemke, 2002 , p. 58). The shift from government to governance can thus be interpreted not as a diminishment or reduction of state sovereignty and planning capacities, but rather as a consolidation of new technologies of government with the dominance of a neoliberal government rationality and the transformation of the technologies of government, from formal to informal techniques and the inclusion of new actors in the governing process (Lemke, 2002).

\section{CONCLUSION}

Globalization and governance are clearly interrelated processes, each with the potential to shape the other. Globalization needs to be understood not as a dynamic, inevitable force, and 'ascribed a kind of ubiquitous causal agency' (Tickell and Peck, 2003, p. 163) which has impacted on states and governance structures, but instead as a process which unevenly and contingently shapes the 'field of action' of governance structures. Domestic governance continues to play a key role in steering and supporting, to varying 
degrees, the pace, extent and impact of global interaction. As Lake (2000) argues, globalization itself 'is the product of a particular form of governance rooted in the domestic political economy of the earlier industrialisers' (p. 32). However, as power has become more diffuse within 'an increasingly complex structure of socio-economic forces and levels of governance' (Cerny, 1999, p. 190) so the capacity of states to influence and participate in global governance has become more differentiated. States have very different capability in terms of exercising power internally and internationally (Jessop, 2004). However, in a global era states with the ability to exercise power both economically and politically should not be construed as the 'unchallenged masters of the global economy'. Nor should we conclude that we are experiencing the 'end of territoriality'. Most appropriate for understanding contemporary politics and policymaking is that they involve processes that are dynamic, dialectical and differentiated. This is an approach that is adopted in the substantive chapters of this book which will provide insight into the spaces and practices of governance (Newman, 2005) under the conditions of globalization.

\section{CONTENT AND STRUCTURE OF THE BOOK}

This edited collection is divided into two parts. The first part explores the concepts and perspectives associated with globalization and governance, the links between them and the implications for the state and public policy. It also considers developments at the global and regional levels and the implications of the emergence of new regulatory regimes in the context of liberalization and privatization. Issues associated with power and politics are key concerns and are integrated into discussions about new approaches to policymaking in governmental and non-governmental settings. The second part focuses on a broad range of substantive areas of public policy such as human rights, health and health care, security, housing markets, poverty and terrorism.

For Adrian Kay one of the key elements of globalization, and a crucial aspect of new governance structures, is the ascendance of economic modes of thinking within the policy process. In Chapter 2 he is concerned with the transcendence of economic logic in the development, implementation and evaluation of public policy, which he argues 'is increasingly wedded to this hallmark of neoclassical economics [cost-benefit analysis]'. In order to explore the relationship between economism and public policy he focuses on three themes: market failure and the policy prescriptions that follow from that; theory of public goods; and government failure as the logic behind many public reforms over the last 20 years. 
In Chapter 3 Kevin Farnsworth looks at the changing nature of corporate power and the growing influence of business in shaping policy interventions both nationally and internationally. His general argument is that business power and influence has been strengthened within global capitalism. However, in developing a theory of business power, Farnsworth stresses the need to differentiate between structural and agency power, and more specifically between institutional frameworks, economic contexts and policy levels.

For Otto Holman in Chapter 4 the power and influence of business in the policy process is also a key concern. The particular focus in this contribution is European governance and the interplay between formal and informal practices of governance. He examines one particular public-private partnership which has developed between transnational business and the European Commission - the European Round Table of Industrialists (ERT) - its influence in relation to the substance of the European Employment Strategy, and role in shaping the European Social Model.

The final chapter (Chapter 5) in Part I looks at governance and the state in Asia, in the context of global neoliberalism. The chapter outlines the policy paradigm of international financial institutions applied to developing countries in the 1980s and contrasts it with the 'counter-critique of the neoliberal paradigm' captured in the concept of the 'developmental state'. Amornsak Kitthananan explores the nature of governance in the developmental states of Japan, South Korea and Taiwan, and the more recent challenges of liberalization and financial crisis to the model of capitalist development. He suggests that recent developments in governance structures in the region, particularly in Thailand, might appropriately be characterized as the emergence of the 'neo-developmental' state.

Part II of this collection focuses on bringing together more general debates in public policy analysis and the policy process, with discussions relating to specific contemporary issues. In so doing it seeks to locate abstractions within specific policy contexts and subsequently illuminate and bring into sharper focus the interdependencies, complexities, diversity and contradictions evident in the current policymaking arena.

In Chapter 6, the focus is on the nature of human rights protection, and its implementation and enforcement. Tonia Novitz begins by outlining the three 'generations' of human rights: civil and political rights; economic, social and cultural rights; and the rights of 'peoples', and the systems and institutions established to implement these rights. She goes on to explain the governance structures surrounding each of the 'generations' of rights and to consider the reluctance of states to strengthen international human rights. The remainder of the chapter goes on to consider whether the pace and depth of global market forces has undermined individual states and 
human rights, and the potential for the increasingly influential international economic institutions to promote and contribute to the protection of human rights on a truly global scale.

Paul Cammack, in Chapter 7, considers the role of global governing elites and international institutions in the making of policies considered appropriate for the alleviation of poverty. He argues that in policy terms a global consensus has emerged around the logics of entrepreneurship and competitiveness. This logic is being transmitted and perpetuated through a range of instruments directed towards poverty policy such as benchmarking, surveillance and peer review. These instruments are promoted by increasingly coordinated global institutions and implemented by national governments, and can best be interpreted as constituting a global 'convergence club' model. Drawing on this model, Cammack highlights the logic and coherence of global policy in relation to povery.

In Chapter 8 Sarah Payne focuses on the contradictory relationship between globalization and health, and the role of health governance in protecting and promoting the well-being of individuals. The chapter considers the uneven distribution of the gains and costs of globalization on health status, as well as the implications of the emergence of new health challenges. Processes of globalization have generated new risks, increased the speed at which such risks can travel and strengthened the necessity for effective global health governance. The chapter concludes by outlining the structure and institutions of global health governance, the impact of these organizations on addressing the negative health impacts of globalization, and the prospects for the future.

Ray Forrest, in Chapter 9, disrupts the traditional national orientation of housing debates and instead locates the discussion in the wider context of global financial integration and global competitiveness. He focuses specifically on home ownership, now the majority tenure and a significant component of global financial flows and national and international financial stability. He reconstructs the shifting relationship between national governments and national housing systems, as more market-based provision has become deeply embedded in global processes and within a more complex institutional architecture. Forrest shows that 'the economic forces which are shaping local housing markets are increasingly supranational', and considers the implications for individual homeowners.

In Chapter 10 Elke Krahmann considers the increasing importance of non-state actors in the security field. She argues that these developments can best be understood as part of a shift from government to governance in North American and European security policymaking. For Krahmann the emerging system of security governance can be mapped in seven dimensions: geography, function, resources, interests, norms, decision-making 
and implementation. Building on a theoretical model which distinguishes between government and governance as two ideal types along these seven dimensions, the chapter explores the growing role of private actors in international security, the problems arising from this transformation of security policymaking and how they could be addressed.

In Chapter 11 Christina Pantazis and Simon Pemberton focus on the dynamics of a multilayered governance in the development of counterterrorism policies in the UK. Whilst analysing the role and influence of actors and institutions at different spatial scales, the authors also assess the influence of specific local and historical contexts and the role of policy transfer in the development of policy initiatives. Thus, this chapter links developments in UK domestic counter-terrorist policies post-9/11 with previous state responses to political violence in Northern Ireland.

In combination, then, the chapters in this collection provide a comprehensive, integrated insight into the relationship between global processes, governance and public policy.

\section{REFERENCES}

Atkinson, M. and W. Coleman (1992), 'Policy networks, policy communities and the problems of governance', Governance, 5 (2), 154-80.

Barry, Andrew, Thomas Osborne and Nikolas Rose (eds) (1996), Foucault and Political Reason: Liberalism, Neo-Liberalism and Rationalities of Government, London: UCL Press.

Biersteker, T.J. (1998), 'Globalization and the modes of operation of major institutional actors', Oxford Development Studies, 26 (1), 15-32.

Burchell, Graham, Colin Gordon and Peter Miller (eds) (1991), The Foucault Effect: Studies in Governmentality, Chicago, IL: University of Chicago Press.

Cerny, Philip G. (1999), 'Globalization, governance, and complexity', in Aseem Prakash and Jeffrey A. Hart (eds), Globalization and Governance, London: Routledge, pp. 188-212.

Clark, Ann Marie, Elisabeth Jay Friedman and Kathryn Hockstetler (2005), 'The sovereign limits of global civil society: a comparison of NGO participation in UN World Conferences on the Environment, Human Rights and Women', in Rorden Wilkinson (ed.), The Global Governance Reader, London: Routledge, pp. 292-321.

DeMars, E. William (2005), NGOs and Transnational Networks: Wild Cards in World Politics, London: Pluto Press.

Eyoh, D. and R. Sandbrook (2001), 'Pragmatic neo-liberalism and just development in Africa', CIS Working Paper 2001-1, University of Toronto, Canada.

Foucault, Michel (1982), 'The subject and the power', in Hubert L. Dreyfus and P. Rabinow (eds), Michel Foucault: Beyond Structuralism and Hermeneutics, Brighton: Harvester, pp. 208-26.

Foucault, Michel (1996), 'Governmentality', in G. Burchell, C. Gordon and P. Miller (eds), The Foucault Effect: Studies in Governmentality, Chicago, IL: University of Chicago Press, pp. 87-104. 
Giddens, Anthony (1999), Runaway World: How Globalization is Reshaping our Lives, London: Profile Books.

Hajer, Marten (2003), 'Policy without polity? Policy analysis and the institutional void', Policy Sciences, 36, 175-95.

Held, David and Anthony McGrew (2000), The Global Transformations Reader, Cambridge: Policy Press.

Held, David and Anthony McGrew (2002), Governing Globalization, Oxford: Polity.

Held, David, Anthony McGrew, David Goldblatt and Jonathan Perraton (1999), Global Transformations: Politics, Economics and Culture, Cambridge: Polity Press.

Hudson, John and Stuart Lowe (2004), Understanding the Policy Process: Analysing Welfare Policy and Practice, Bristol: Policy Press.

Jessop, Bob (2004), 'Hollowing out the "nation-state" and multi-level governance', in Patricia Kennett (ed.), A Handbook of Comparative Social Policy, Cheltenham, UK and Northampton, MA: Edward Elgar.

Kjaer, Anne Mette (2004), Governance, Cambridge: Polity.

Kooiman, Jan (1993), 'Social-political governance', in Jan Kooiman (ed.), Modern Governance, London: Sage, pp. 1-6.

Kooiman, Jan (2003), Governing as Governance, London: Sage Publications.

Lacher, Hannes (2005), 'International transformation and the persistence of territoriality: toward a new political geography of capitalism', Review of International Political Economy, 12 (1), 26-52.

Lake, David A. (2000), 'Global governance: a relational contracting approach', in Aseem Prakash and Jeffrey A. Hart (eds), Globalization and Governance, London: Routledge, pp. 31-53.

Lemke, Thomas (2001), "The birth of bio-politics": Michel Foucaults's lecture at the College de France on neo-liberal governmentality', Economy and Society, 3 (2), 190-207.

Lemke, Thomas (2002), 'Foucault, governmentality, and critique', Rethinking Marxism, 14 (3), 49-64.

Lipschutz, I. (1992), 'Reconstructing world politics: the emergence of global civil society', Millennium, 21 (3), 300-420.

Marsh, David and Martin J. Smith (2000), 'Understanding policy networks: towards a dialectical approach', Political Studies, 48, 4-21.

McGee, Rosemary with Josh Levene and Alexandra Hughes (2002), Assessing Participation in Poverty Reduction Strategy Papers: A Desk-Based Synthesis of Experience in Sub-Saharan Africa, Brighton: Institute of Development Studies.

McGinnis, Michael D. (2000), 'Rent-seeking, redistribution, and reform in the governance of global markets', in Aseem Prakash and Jeffrey A. Hart (eds), Globalization and Governance, London: Routledge, pp. 54-76.

Newman, Janet (ed.) (2005), Remaking Governance: Peoples, Politics and the Public Sphere, Bristol: Policy Press.

Oxfam International (2006), 'Kicking the habit: how the World Bank and the IMF are still addicted to attaching economic policy conditions to aid', Oxfam Briefing Paper 96.

Pierre, Jon (ed.) (2000), Debating Governance: Authority, Steering, and Democracy, Oxford: Oxford University Press.

Porter, Doug and D. Craig (2004), 'The third way and the third world: poverty reduction and social inclusion in the rise of "inclusive" liberalism', Review of International Political Economy, 11 (2), 387-423. 
Rhodes, Rod A.W. (1996), 'The new governance: governing without government', Political Studies, 44, 652-67.

Rhodes, Rod A.W. (1997), Understanding Governance: Policy Networks, Governance, Reflexivity and Accountability, Basingstoke: Macmillan.

Rhodes, Rod A.W. (2000), 'Governance and public administration', in Jon Pierre (ed.), Debating Governance: Authority, Steering and Democracy, Oxford: Oxford University Press, pp. 54-90.

Richards, David and Martin J. Smith (2002), Governance and Public Policy in the United Kingdom, Oxford: Oxford University Press.

Rose, Nikolas and Peter Miller (1992), 'Political power beyond the state: problematics of government', British Journal of Sociology, 43, 173-205.

Rosenau, James N. (1990), Turbulence in World Politics: A Theory of Change and Continuity, Princeton, NJ: Princeton University Press.

Scholte, Jan Aart (2000), Globalization: A Critical Introduction, Basingstoke: Palgrave.

Sinclair, Scott (2003), 'The WTO and its GATS', in Jonathan Michie (ed.), The Handbook of Globalisation, Cheltenham, UK and Northampton, MA, USA: Edward Elgar Publishing, pp. 347-57.

Stoker, G. (1998), 'Governance as theory: five propositions', International Social Science Journal, 50 (155), 17-28.

Swyngedouw, E. (2005), 'Governance innovation and the citizen: the Janus Face of governance-beyond-the-state', Urban Studies, 42 (11), 1991-2006.

Tickell, Adam and Jamie Peck (2003), 'Making global rules: globalization or neoliberalization?', in Jamie Peck and Henry Wai-chung Yeung (eds), Remaking the Global Economy, London: Sage, pp. 163-82.

UNDP (2000), The Human Development Report: Human Rights and Human Development, Oxford: Oxford University Press.

UNDP (2002), Human Development Report 2002: Deepening Democracy in a Fragmented World, Oxford, New York: Oxford University Press.

Weiss, Linda (1991), Industry in Developing Countries: Theory, Policy and Evidence, London: Routledge.

Weiss, Linda (1998), The Myth of the Powerless State, Cambridge: Polity.

Weiss, Linda (2005), 'The state-augmenting effects of globalisation', New Political Economy, 10 (3), 345-53.

Wilkinson, R. (2005), 'The Commission on Global Governance: a new world', in R. Wilkinson (ed.), The Global Governance Reader, London: Routledge, pp. 26-44. 